\title{
相対的な人口集中地区の抽出を通じた全国市町村の都市縮小傾向の分析
}

一人口減少時代を迎えるわが国の都市圈の形態変化に関する研究(その 2 ) -

\section{AN ANALYSIS ON URBAN SHRINKAGE TRENDS OF ALL JAPANESE CITIES VIA DETECTING RELATIVE DENSELY INHABITED DISTRICT}

- Urban form changes of Japanese cities in an era of shrinking population part 2 -

$$
\text { 川邊晃大蒲, 渡辺俊*2 }
$$

\section{Akihiro KAWABE and Shun WATANABE}

\begin{abstract}
For analyzing method of the urban shrinkage, Densely Inhabited District (DID) has been applied in some past studies as an index of urban areas or city centers. As an issue of this method, shrinkage in the cities where no DID exist can't be analyzed. Therefore, a relative threshold of urban area or city centers is needed. In this paper, we proposed the detecting method of Relative Densely Inhabited District (RDID) improved by "Information Loss Minimization”. Furthermore, we identified the urban shrinkage or structure changes in Japanese cities using RDID and analyzed the changing trends from 1995 to 2015.
\end{abstract}

Keywords : Information Loss Minimization, Urban structure, Stages of urban development, Standard grid cell, Entropy, Relative Densely Inhabited District 情報量損失最小化法, 都市構造, 都市発展段階, 標隻地域メッシュ, 平均情報量, 相対的人口集中地区

1. はじめに

\section{1 背景 $\cdot$ 目的}

本格的な人口減少時代に突入し、無計画な都市縮小が顕在化し始 めた現在では、今一度冷静にその実態を把握することの必要性が指 摘されている1)。こうした指摘にも表れているように、現在までに 発生してきた都市の縮小化の様相を全国的に振り返り、傾向の変化 を俯瞰的に分析することで各自治体における縮小後の都市像の予見 や人口減少時代の都市計画の指針策定に資する知見が得られると考 えられる。しかしながら全国の市町村単位における直近の複数期間 における都市縮小傾向を把握する試みは多くない。

ここで、各市町村における都市縮小傾向を把握しようとする場合、 どの程度の人口密度を有する地域までを当該圈域の市街地あるいは 中心地区として捉えるべきかを議論することが必要となる。一般的 な高密度な地域の規定としては DID（人口集中地区）が存在してお り、実際にDID やそれに準じた領域を市街地や中心部と見なして都 市縮小傾向を分析する研究も見られる。しかし市町村圈域によって は DID が存在しない場合もあり、反対にほぼ全域が DID であるよ うな市町村も存在する。すなわち、市町村圈域における中心地区と して認められる地域の基準は相対的なものであり、全国の市町村ご とに異なる中心的地域の縮小傾向を DID という統一的な基準をも とに分析することには限界があると言える。

これに関して、筆者らは前稿 2)にて Amindarbari ら（2013）3)の
都市圈中心核抽出方法を応用することで対象圈域における相対的な 密度基準と人口基準に基づく「相対的人口集中地区（Relative Densely Inhabited District :RDID)」を抽出し、その縮小を都市縮 小の指標とすることで DID が存在しないような小規模圈域等にお いても適用可能な都市縮小傾向分析の一例を示した。このように全 国的な市町村圈域における都市縮小傾向を把握に際しては、各市町 村圈域の規模に応じた相対的基準での人口集中地区を規定し、それ に基づいた傾向分析を行うというアプローチが有効だと考えられる。 一方、前稿の方法による RDID の抽出に関しては大規模な圈域で 密度基準が過大になり、それを回避するために密度基準設定式中の 係数を引き下げると今度は小規模な圈域において基準值が過少とな りやすい等の問題が存在する。また詳細は後述するが、前稿の RDID はその縮小を観測する際に密度基準の未達による縮小と人口基準の 未達による縮小を同一視することになるという問題もある。

ここで、上記の密度基準の設定上の問題については各市町村圏域 の規模に応じて適切に「相対的に人口密度が高い地区群」と「相対 的に人口密度が高いと言えない地区群」の 2 クラスに切り分けるよ うな密度基準設定方法を RDID 抽出プロセスの中に取り入れること で解決できる。このような空間データの属性值の大きさに基づくク ラス分けを適切な形で行う手法として、大佛（2003）44はラス分 けの際に失われる情報の少なさを基準とする情報量損失最小化法を 提案している。この手法を密度基準の設定に応用することで対象圈

\footnotetext{
*1 都市再生機構 修士(社会工学)

(元筑波大学大学院システム情報工学研究科大学院生)

*2 筑波大学システム情報系 教授・博士 (工学)
}

Urban Renaissance Agency, Master of Policy and Planning Sciences

(Former Grad. Student, Graduate School of Systems and Information Engineering, Univ. of Tsukuba)

Prof., Faculty of Engineering, Information and Systems, Univ. of Tsukuba, Ph.D. in Eng. 
域の空間データに固有の順位分布の特性を「情報量の劣化が最小で ある」という意味においてより適切に捉えた相対的な人口集中地区 の基準值を得ることが期待できる注 ${ }^{1)}$ 。以上のことを背景として、本 研究では先述の情報量損失最小化法を応用した相対的人口集中地区 （RDID）の抽出方法を提案する。その後、1995 年〜2015 年の間の 複数年における RDID の抽出を通じて直近の期間における全国の市 町村圈域の都市縮小傾向に関する知見を得ること目的とする。

\section{2 研究の方法}

本稿では初めに情報量損失最小化法を概説し、それを応用した本 稿における RDID の抽出方法を提示する。その後、1995 年から 2015 年までの期間について 5 年間隔 4 期間に分割し、各期間における全 国の市町村の都市縮小傾向の変化を明らかにする。なお、本研究で は全国の市町村の都市縮小傾向について「都市構造変容傾向」と「中 心地の面的縮小傾向」の 2 つの観点に切り分けて考える。そしてこ の 2 観点からの都市縮小傾向について RDID を用いて分析する。

前者については各市町村圈域の RDID を中心部、その外部を郊外 部と見なし、それぞれの領域の人口増減に基づいて各期間における 各市町村の都市構造変容類型を定める。そして各都市構造変容類型 に属する市町村数の変遷を分析することで都市構造変容の観点から の全国の市町村の都市縮小傾向を明らかにする。

後者については実質的な RDID 領域の面的な縮小を都市縮小の指 標とすることで都市縮小の発生・非発生状況や具体的な発生位置に 関する傾向变化を分析する。具体的に、まず各期間における都市縮 小発生市町村数推移を明らかにする。その後 RDID の部分的縮小発 生地域と RDID 非縮小地域の間の空間的接続関係の指標化を通じて RDID 縮小の発生位置に関する経年的傾向変化を把握する。

\section{3 既往研究レビューおよび本研究の独自性}

近年における全国的な都市縮小傾向あるいは都市構造変容に関す る研究を概観する。金ら（2007） 5)は 1970 年から 2000 年までの期 間についてクラーセンの都市発展段階仮説に基づく分類を用いて 30 年間の全国の都市圏の都市構造変化傾向を分析している。有賀ら (2011）6) はメッシュ単位の自然・社会増減が市域内の人口分布の 偏りに対してどの程度寄与したかを分析した。清水 (2015) 7)、菊池 ら（2015）8、高柳（2017）99は $1 \mathrm{~km}$ メッシュ単位で集計された都 市的あるいは自然的土地利用の増加・減少傾向と人口や世帯の増加・ 減少傾向に着目し、メッシュ単位での全国的な都市縮小傾向分析を 行っている。また浅野ら（2014）10)、原ら（2015）11はDID の縮小 区域を市街地縮小区域と規定し、全国規模での DID 縮小地域に関す る地域類型化や線引き制度の運用形態との関係性を考察している。

上記の様に全国的な都市縮小あるいは都市構造変容の傾向を明ら かにしようとする研究には一定の蓄積がある。一方で全国の全ての 市町村圈域に対して相対的な人口集中地域を抽出し、都市縮小発生 実態や都市構造変容を分析している例はない。また現在に近い複数 年のデータを用いて、都市縮小や都市構造変容の経年的な傾向変化 を追う研究は少ない。こうした点に本研究の独自性がある。

\section{2. 情報量損失最小化法の概説}

情報量損失最小化法は空間データを対象数值の大きさに基づいて
クラス分けする際に、原データの持つ情報の劣化が最小となるよう に分類する方法である。大まかな手続きとしては、まずソートされ た原データを $m$ 個のクラスに分類する $m-1$ 個の境界值を変動させ ながら、各場合でクラス分けを行った時の原データの情報の劣化を 「情報量損失率（\%）：L」として指標化する。そしてLの值が最小と なる境界值の組み合わせによるクラス分けを採用する。注2) 注3)

手法の前提として、空間データが表現する観測対象物の空間分布 は各地点に固有の分配確率に基づいて観測対象物が分配された実現 值だと考える。そして原データをクラス分けした際には、同一クラ スに属する地点の分配確率は均一なものであると見なす。原データ が表す各地点における分配確率の確率分布の平均情報量を $I_{0} 、 ク ラ$ ス分け後のデータが表す分配確率の確率分布の平均情報量をI とし たとき、 $L$ は $I-I_{0}$ と $I_{0}$ との比率として表される。具体的に、各地点 $i(i=1,2, \ldots, n)$ における観測対象物の数量を $x_{i}$ とし、原データ $x_{i}(i=$ $1,2, \ldots, n)$ を $m$ 個のクラス $C_{k}(k=1,2, \ldots, m)$ に分類するとした場合、 $I_{0} 、 I 、 L$ はそれぞれ次の式 $(1) 、(2) 、(3)$ で計算できる。

$$
\begin{aligned}
& I_{0}=-\sum_{i=1}^{n} p_{i} \log _{2} p_{i} \text { ただし } p_{i}=\frac{x_{i}}{\sum_{j=1}^{n} x_{j}} \\
& I=-\sum_{k=1}^{m} N_{k} q_{k} \log _{2} q_{k} \text { ただし } q_{k}=\frac{\sum_{i \in G_{k}} x_{i}}{N_{k} \sum_{j=1}^{n} x_{j}} \\
& L=\frac{I-I_{0}}{I_{0}} \cdot 100
\end{aligned}
$$

$N_{k}$ はクラス $C_{k}$ に含まれるデータの個数であり $G_{k}$ は $C_{k}$ に含まれるデ 一タの添え字の集合である。また $p_{i}$ は原データにおける地点 $i$ の分配 確率であり、 $q_{k}$ はクラス分け後にクラス $C_{k}$ に分類された地点が共有 する分配確率である注4)

\section{3. 本稿における相対的人口集中地区（RDID）の抽出}

前稿および本研究における RDID の抽出基準をまとめた表を Table 1 に示す。前稿の基準設定方法は極端に常住人ロデータの標 準偏差の大きくなるような大規模な圈域において密度基準が過大に なりやすく、それを避けるために式中の係数を引き下げると小規模 な圏域において基準值が過少となりやすい。また、前稿の RDID は DID の定義に準じて「密度基準による高密度単位区の抽出」と「人 口基準による小人口連坦単位区の除外」という手続きを経て抽出さ れている。そのため、RDID の面的な縮小を観測する際には密度基

\begin{tabular}{|c|c|c|}
\hline & $\begin{array}{c}\text { 前稿における RDID } \\
\text { RDID in previous paper } \\
\end{array}$ & $\begin{array}{l}\text { 本稿にお抒る RDID } \\
\text { RDID in this paper }\end{array}$ \\
\hline $\begin{array}{l}\text { inimum } \\
\text { nit area }\end{array}$ & $\begin{array}{l}500 \mathrm{~m} \text { メッシュ } \\
500 \mathrm{~m} \text { mesh }\end{array}$ & $\begin{array}{l}500 \mathrm{~m} \text { メシシュ } \\
500 \mathrm{~m} \text { mesh }\end{array}$ \\
\hline $\begin{array}{l}\text { Density } \\
\text { threshold }\end{array}$ & \begin{tabular}{|c|c} 
& $m:$ 平均 \\
& Mean of data \\
$m+2 s$ & $s:$ 標淮偏差 \\
& Standard \\
& deviation \\
\end{tabular} & 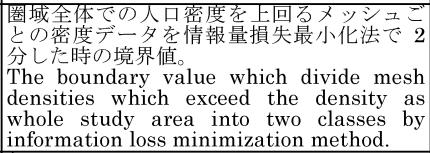 \\
\hline $\begin{array}{l}\text { opulation } \\
\text { areshold }\end{array}$ & 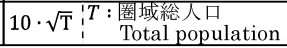 & \begin{tabular}{|l} 
無 L \\
Limitless
\end{tabular} \\
\hline
\end{tabular}
準の未達による縮小と人口基準の未達による縮小を同一視すること になるという問題もある。

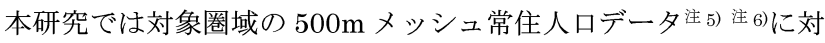
して前稿の密度基準の代わりに人口密度を対象数值とした情報量損 失最小化法を応用して得た密度基準を適用することで当該圈域の 
RDID を抽出する。具体的な抽出の流れとして、まず対象圈域にお ける圈域全体で見た人口密度を上回るメッシュを抽出する。その後、 抽出されたメッシュに対してさらに上位クラスと下位クラスに 2 分 するように情報量損失最小化法（対象数值は人口密度）を適用し、 その結果として上位クラスに分類されたメッシュを RDID とする (Fig. 1)。上記の方法で規定された RDID は「圈域全体で均した密 度を超える単位区群からより一層高密度である区域」を情報量の劣 化が最小という意味で適切に抽出したものとして考えることができ る。したがって本研究での RDID に関してはどのような規模の圈域 に対しても当該圈域のデータに固有の順位分布の特性を適切に反映 した基準にもとづいて規定されるため過大・過小評価等の問題が生 じないと言える。

なお、本研究では RDID の人口基準をあえて設けないことで、 RDID 縮小傾向の分析時における密度基準の未垟による縮小と人口 基準の未達による縮小の混同の問題を回避している。

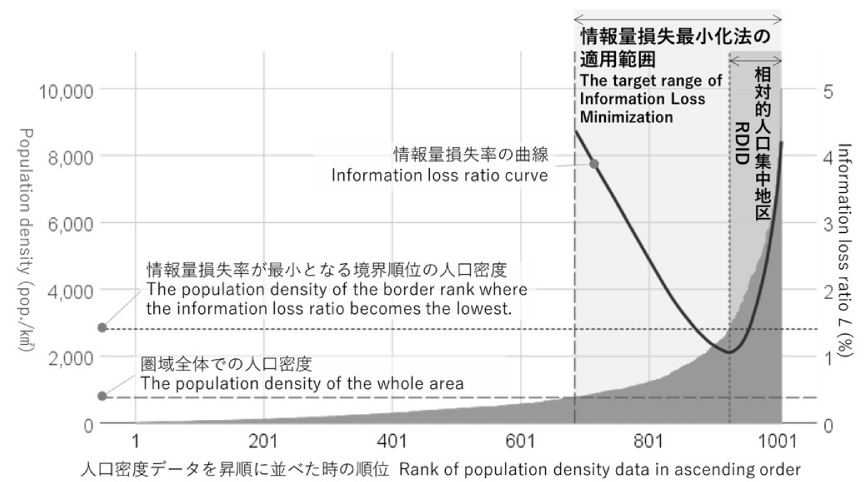

Fig. 1 A image of Detecting RDID

\section{RDID に基づく都市構造変容傾向の分析}

まず、全国の 1719 の市町村圈域における 1995 年 2015 年間の 都市構造変容傾向を分析する注7)。本研究では各期間で都市構造変容 を規定する際、各期間の前の年の人口データに基づき規定された RDID 領域を中心部、その外部を郊外部とみなす。そして前の年か ら 5 年後の年にかけての中心部・郊外部の人口増減に基づきその期 間の都市構造変容を規定する。具体的に、金ら (2007) 5)の研究を参 考に Table 2 に示す分類表に従い都市構造変容類型を規定した注 8 。

Table 2 Changing type of urban structure in this paper

\begin{tabular}{|c|c|c|c|c|}
\hline $\begin{array}{l}\text { 豦市構造変容類型 } \\
\text { Changing type of } \\
\text { urban structure }\end{array}$ & $\begin{array}{l}\text { 圈域総人口 } \\
\text { Total pop. }\end{array}$ & $\begin{array}{l}\text { RDID 人口 } \\
\text { RDID pop. }\end{array}$ & $\begin{array}{l}\text { RDID 外部人口 } \\
\text { Outside pop. } \\
\text { of RDID }\end{array}$ & $\begin{array}{l}\text { RDID 人口比 } \\
\text { Population } \\
\text { rate of RDID }\end{array}$ \\
\hline \begin{tabular}{|l} 
1)都市化 (絶対的集中) \\
(1) Urbanization \\
(Absolute centralization)
\end{tabular} & + & + & - & + \\
\hline $\begin{array}{l}\text { 2) 都市化 (相対的集中) } \\
\text { (2) Urbanization } \\
\text { (Relative centralization) }\end{array}$ & + & + & + & + \\
\hline $\begin{array}{l}\text { (3) 郊外化 (相対的分散) } \\
\text { (3) Suburbanization } \\
\text { (Relative decentralization) }\end{array}$ & + & + & + & - \\
\hline $\begin{array}{l}\text { (4) 郊外化 (絶效的分散) } \\
\text { (4) Suburbanization } \\
\text { (Absolute decentralization) }\end{array}$ & + & - & + & - \\
\hline $\begin{array}{l}\text { 5)逆都市化 (絶就的分散) } \\
\text { 5) Disurbanization } \\
\text { (Absolute decentralization) }\end{array}$ & - & - & + & - \\
\hline $\begin{array}{l}\text { 6)逆都市化 (相対的分散) } \\
\text { 6Disurbanization } \\
\text { (Relative decentralization) }\end{array}$ & - & - & - & - \\
\hline $\begin{array}{l}\text { (7) 再都市化 (相的的集中) } \\
\text { 7) Reurbanization } \\
\text { (Relative centralization) }\end{array}$ & - & - & - & + \\
\hline $\begin{array}{l}\text { 8)再都市化 (絶詨的集中) } \\
\text { 8Reurbanization } \\
\text { (Absolute centralization) }\end{array}$ & - & + & - & + \\
\hline
\end{tabular}

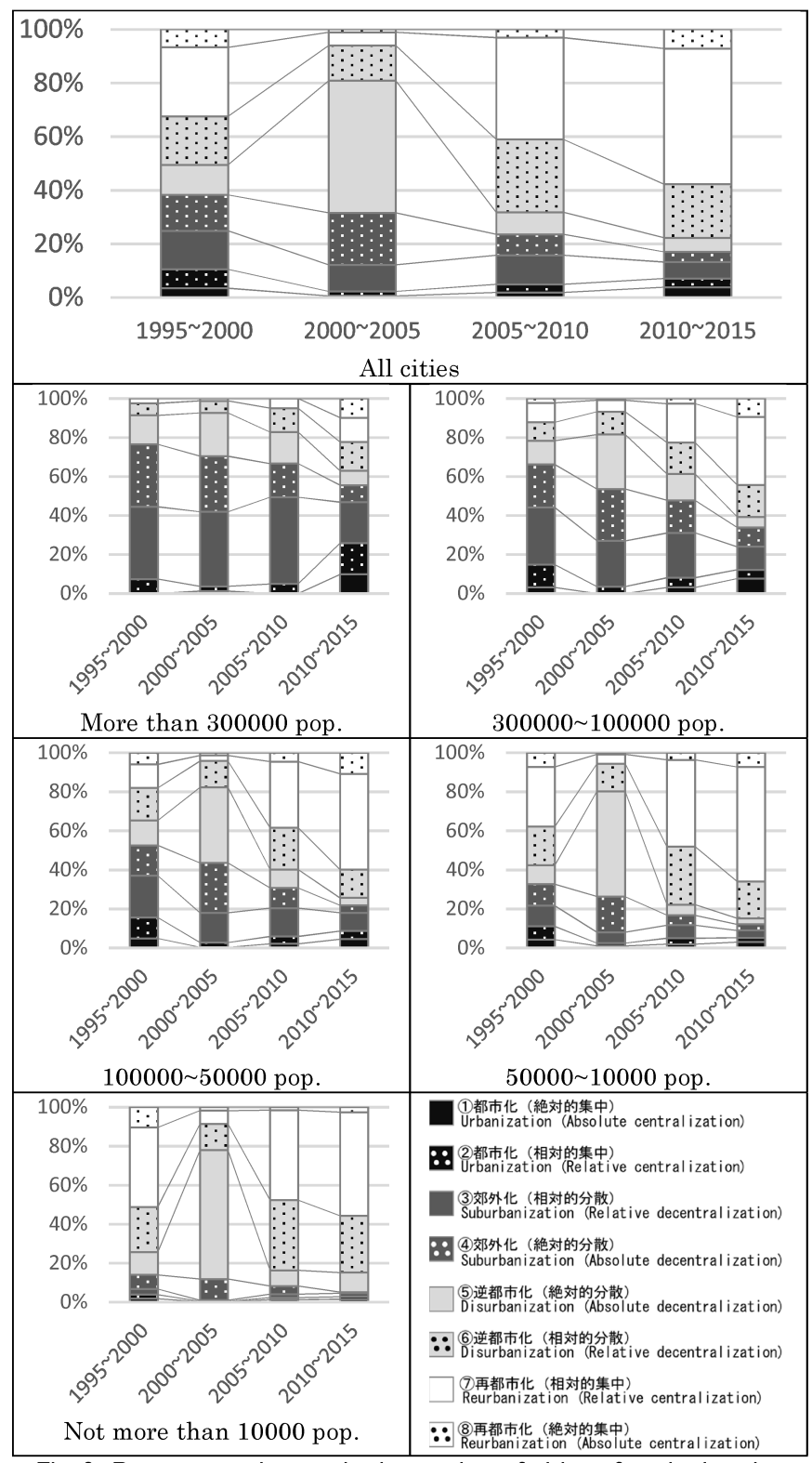

Fig. 2 Percentage changes in the number of cities of each changing type in each population size

Fig. 2 に各期間における各市町村の都市構造変容類型を、Fig. 3 に 市町村全体および 1995 年時点人口規模別に各類型の圈域数の推移 を表したグラフをそれぞれ示す。市町村全体に着目すると、2000 年 ２005 年の期間において絶対的分散の傾向（4)、(5)）にある圈域が 急増し、続く 2005 年 2010 年の期間では急減している様相が確認 できる。これと対照的に再都市化の傾向 (7)、8) にある圏域は 2000 年 2005 年にて急減し、2005 年 2010 年の期間では急増している。 2005 年 2010 年の期間以降も再都市化の傾向にある圈域の増加は 続いている。また都市化の類型（11、(2)）も同期間で増加傾向にあ る。このことから全国の市町村は 2000 年 2005 年の期間以降は人 口分布構造としては集中化（1、(2)、(7)、(8)）の方向に向かってい ることが読み取れる。一方で 2005 年 2010 年以降の集中化傾向に ある圈域の大半は「(7)再都市化 (相対的集中)」に属している。この ことから人口比としての RDIDの比重は高まりつつも多くの圈域の 中心部の密度低下が続いていることが伺える。 


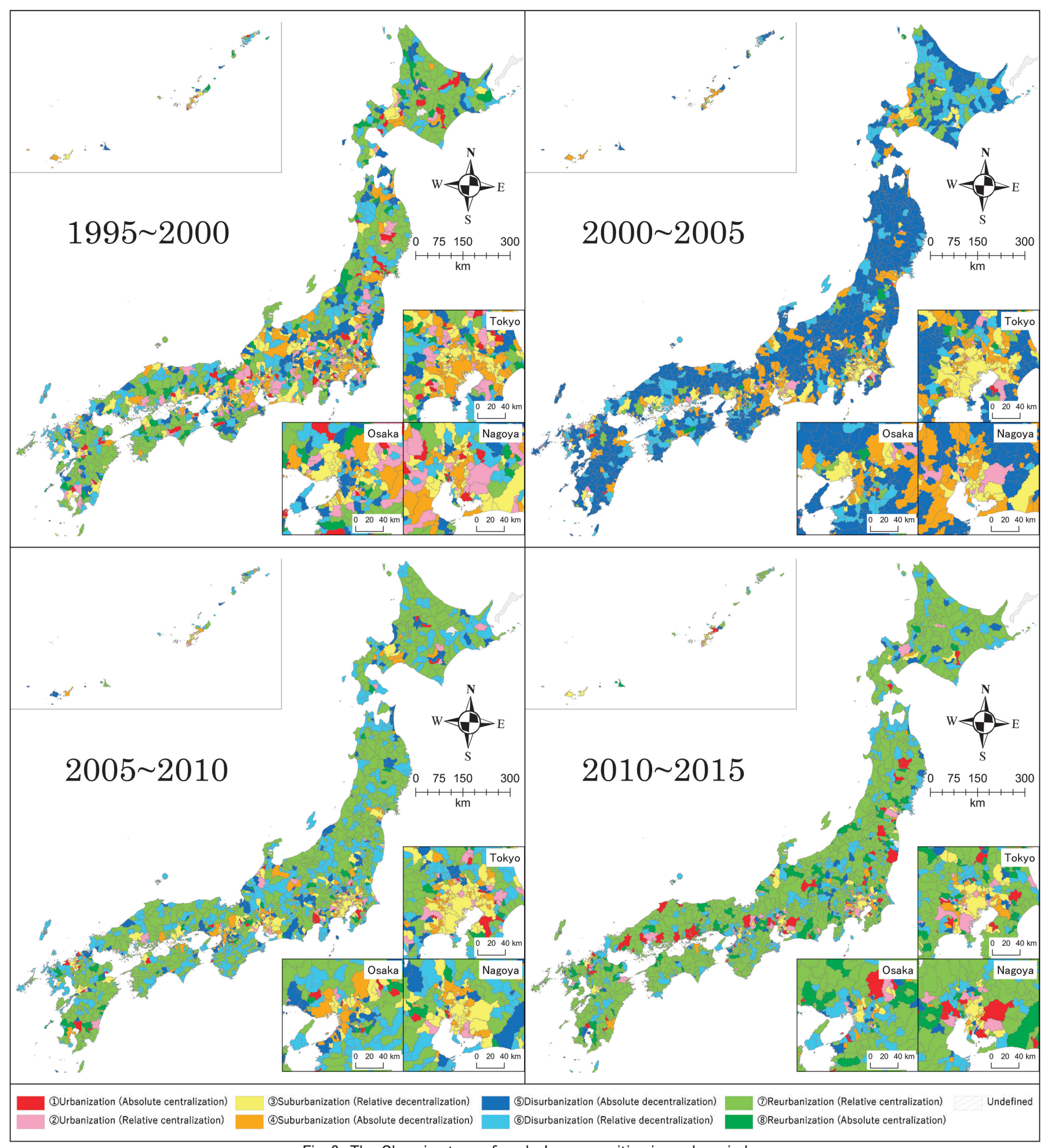

Fig. 3 The Changing type of each Japanese cities in each period

人口規模別に作成したグラフに着目すると、比較的大規模な圈域 では郊外化の傾向（3、(4)）にある圈域が 2005 年 2010 年の期間 まで目立っていた。一方で 2010 年 2015 年の期間ではその傾向が 薄れ、対照的に再都市化や都市化の傾向にある圈域の増加が見られ る。また小規模な圈域群ほど 2000 年 2005 年の期間の類型におけ る「(5)逆都市化 (絶対的分散)」に属する圈域の増加が著しく、以降 の期間の「(7)再都市化 (相対的集中)」に属する圈域の増加も著しい。 ここで、2000 年 2005 年の期間の全国的な市町村における絶対
的分散傾向について、2000 年と 2005 年の国勢調查結果の間に存在 するメッシュ人口同定方法の変更が影響している可能性を検討する。 標準地域メッシュの人口は国勢調査結果の集計の最小単位である基 本単位区の人口を各メッシュに割り当てることで同定される。総務 省統計局が公開する資料 12 )を参照すると 2000 年までは複数のメッ シュにまたがる $0.05 \mathrm{~km}$ 以上の基本単位区から各メッシュへの人口 の割り当てには「人口分布点同定」などの一点集約的な方法が用い られていた。一方で 2005 年以降は「住宅建物同定」などの建物立 
地情報を参照したより精密な方法が用いられている（Table 3)。し たがって、2000 年のデータ整備時点で単位区人口が単一メッシュへ 一点集約的に配分されていた地域が、2005 年のデータ整備時点では 複数のメッシュに幅を持って人口が配分されるようになったと言え る。実際に、ある年の時点では無人であるものの、次の調查実施年 では有人であるような全国の $500 \mathrm{~m}$ メッシュの数とそうしたメッシ ユにおける増加人口の全国総計を 1995 年から 2015 年までの各期 間で調べると、 2000 年 2005 年の期間ではメッシュ数、増加人口総 計共に他期間と比較して著しく大きな值となっている（Table 4)。

以上のことから、2000 年 2005 年の期間では一点集約的に人口 が付与されていた高密度なメッシュから周囲のメッシュへの人口流 出がデータの見かけ上で観測されやすくなっていることが推察され る。したがって 2000 年 2005 年の期間における全国的な分散化傾 向は上記のメッシュ人口の同定方法の変更の影響を受けたものであ る可能性が否定できない。

Table 3 Identification method of mesh population from crossed unit zone in each year

\begin{tabular}{|c|c|c|c|c|}
\hline & \multicolumn{4}{|c|}{ 基本単位区の大きさ The basic unit zone area } \\
\hline & Less than $0.05 \mathrm{~km}$ & Less than $0.1 \mathrm{kml}$ & $\begin{array}{l}\text { Less } \\
\text { than } \\
0.25 \mathrm{kml}^{2}\end{array}$ & $0.25 \mathrm{kmll}^{2}$ and over \\
\hline ڤ̊ㅠ & $\begin{array}{c}\text { Inside of DID } \Rightarrow(\mathrm{A}) \\
\text { PDP exists } \Rightarrow(\mathrm{B}) \\
\text { The others } \Rightarrow(\mathrm{C})\end{array}$ & $\begin{array}{l}\text { PDP exists } \Rightarrow(\mathrm{B}) \\
\text { The others } \Rightarrow(\mathrm{C})\end{array}$ & & (B) \\
\hline ๕̊̊̆ & (A) & \multicolumn{2}{|l|}{$\begin{array}{l}\text { PDP exists } \Rightarrow(\mathrm{B}) \\
\text { The others } \Rightarrow(\mathrm{C})\end{array}$} & (B) \\
\hline $\mid \begin{array}{ll}1 & 0 \\
0 & 0 \\
0 & 0 \\
0 & 0\end{array}$ & (A) & \multicolumn{2}{|l|}{$\begin{array}{c}\text { RBD exists } \Rightarrow(D) \\
\text { OBD exists } \Rightarrow(\mathrm{E}) \\
\text { PDP exists } \Rightarrow(\mathrm{B}) \\
\text { The others } \Rightarrow(\mathrm{C})\end{array}$} & $\begin{array}{c}\text { RBD exists } \Rightarrow(\mathrm{D}) \\
\text { OBD exists } \Rightarrow(\mathrm{E}) \\
\text { PDP exists } \Rightarrow(\mathrm{B})\end{array}$ \\
\hline 尽 & \multicolumn{4}{|c|}{$\begin{array}{l}\text { The habitable area is more than } 10 \mathrm{~m}^{2} \text { and less than } 5000 \mathrm{~m}^{2} \Rightarrow(\mathrm{F}) \\
\text { RBD exists } \Rightarrow(\mathrm{D}) \\
\text { PDP exists } \Rightarrow(\mathrm{B}) \\
\text { OBD exists } \Rightarrow(\mathrm{E}) \\
\text { The basic unit zone area is less than } 5000 \mathrm{~m}^{2}\left(0.005 \mathrm{kll}^{2}\right) \Rightarrow(\mathrm{A}) \\
\text { The others } \Rightarrow(\mathrm{C})\end{array}$} \\
\hline
\end{tabular}
(※) PDP / 人口分布点 Population distributed point RBD / 住宅建物データ Residential building da
$\mathrm{OBD}$ / 事業所建物データ Office building data

【面積割合同定 Area ratio identification】

（A）基本単位区と重なる面積の比に応じて人口を配分（面積按分）する。 Distributing the basic unit zone population to overlapped meshes according to the overlapped area ratio.

【人口分布点同定 Population distributed point identification】 基本単位区の人口分布点が存在するメッシュに人口を配分する。分布点を複 B) 数持つ場合は各点に均等に配分する。

Distributing the basic unit zone population to the mesh where a population distributed point exists. If the basic unit zone has multiple points, the population is distributed to each point equally.

【図心同定 Centroid identification】

（C）基本単位区の幾何学的重心点が存在するメッシュに全人口を配分する。

Distributing the basic unit zone population to the mesh where the centroid of the zone exists.

【住宅建物同定 Residential building identification】

住宅建物データと基本単位区、メッシュを重㸚合わせ、各建物に付与されて

いる戸数を重みとして人口を配分する。

Distributing the basic unit zone population to overlapped meshes according to the number of houses, using the residential building data in the zone

【事業所建物同定 Office building identification】

事業所建物データと基本単位区、メッシュを重㸚わせ、事業所数を重みと

E) して人口を配分する。

Distributing the basic unit zone population to overlapped meshes according to the number of office building, using the office building data in the zone

【可住地面積割合同定 Habitable area identification】

建物データと基本単位区、メッシュを重㸚合わせ、居住可能な建物の建物面

，積に応じて人口を配分する。

Distributing the basic unit zone population to overlapped meshes according to the area of habitable building, using the building data in the zone
Table 4 The number of applicable meshes for each condition

\begin{tabular}{|l|r|r|}
\cline { 2 - 3 } & $\begin{array}{l}\text { Number of } \\
\text { applicable } \\
\text { meshes }\end{array}$ & $\begin{array}{l}\text { Total increased } \\
\text { pop. of applicable } \\
\text { meshes }\end{array}$ \\
\hline $\begin{array}{l}\text { Uninh 年時点で無人、2000 年時点で有人 } \\
\text { United in } 1995 \text { but inhabited in 2000. }\end{array}$ & 5,755 & 416,668 \\
\hline $\begin{array}{l}2000 \text { 年時点で無人、2005 年時点で有人 } \\
\text { Uninhabited in } 2000 \text { but inhabited in 2005. }\end{array}$ & 187,461 & $4,550,941$ \\
\hline $\begin{array}{l}2005 \text { 年時点で無人、2010 年時点で有人 } \\
\text { Uninhabited in } 2005 \text { but inhabited in 2010. }\end{array}$ & 14,972 & 156,315 \\
\hline $\begin{array}{l}2010 \text { 年時点で無人、2015 年時点で有人 } \\
\text { Uninhabited in } 2010 \text { but inhabited in 2015. }\end{array}$ & 20,931 & 137,260 \\
\hline
\end{tabular}

\section{RDID の面的縮小に基づく都市縮小傾向の分析 \\ 5.1 都市縮小発生市町村数の推移}

本研究では RDID の面積変化を指標として都市縮小を規定する。 しかし RDID は年次によって基準值が異なるため、異なる年の間で RDID 面積を比較することは適切でない。そこで本研究では各期間 における前の年の RDID 抽出基準を直接その 5 年後の年のデータに 適用することで得られる領域を 5 年後の年の「相対的人口集中地区' (RDID’)」と定義する。そして 5 年後の年の RDID’ 面積と前の 年の RDID 面積の差に基づき各期間の各圈域における都市縮小を判 断することとした（Table 5)。なお都市拡大についても同様な方法 で判断し、都市縮小発生状況と比較しつつ経年的傾向変化を調べる。

Table 5 Detection of RDID area change and urban shrinkage or expansion in this paper

\begin{tabular}{|c|c|c|c|c|c|}
\hline & $\begin{array}{l}\text { Population } \\
\text { data in } 1995\end{array}$ & $\begin{array}{l}\text { Population } \\
\text { data in } 2000 \\
\end{array}$ & $\begin{array}{l}\text { Population } \\
\text { data in } 2005 \\
\end{array}$ & $\begin{array}{l}\text { Population } \\
\text { data in } 2010 \\
\end{array}$ & $\begin{array}{l}\text { Population } \\
\text { data in } 2015 \\
\end{array}$ \\
\hline \begin{tabular}{|l|}
1995 年の密度基準 \\
Density threshold in 1995
\end{tabular} & $\begin{array}{c}1995 \text { 年の } \\
\text { RDID }\end{array}$ & $\begin{array}{l}2000 \text { 年の } \\
\mathrm{RDID}\end{array}$ & & & \\
\hline $\begin{array}{l}2000 \text { 年の密度基準 } \\
\text { Density threshold in } 2000\end{array}$ & & $\begin{array}{c}2000 \text { 年の } \\
\text { RDID } \\
\end{array}$ & $\begin{array}{l}2005 \text { 年の } \\
\text { RDID' }\end{array}$ & & \\
\hline \begin{tabular}{|l|}
2005 年の密度基準 \\
Density threshold in 2005
\end{tabular} & & & $\begin{array}{c}2005 \text { 年 } \\
\text { RDID }\end{array}$ & $\begin{array}{l}2010 \text { 年の } \\
\text { RDID' }\end{array}$ & \\
\hline \begin{tabular}{|l|}
2010 年の密度基準 \\
Density threshold in 2010
\end{tabular} & & & & $\begin{array}{l}2010 \text { 年 } \\
\text { RDID }\end{array}$ & $\begin{array}{l}2015 \text { 年の } \\
\text { RDID' }\end{array}$ \\
\hline
\end{tabular}

市町村全体および 1995 年時点の人口規模別に都市縮小・拡大の 発生圏域数の推移を表したグラフを Fig. 4 に示す。市町村全体を見 ると、全国の都市縮小圏域の総数は増加傾向にあることが分かる。 特に人口減少下で都市縮小を呈する市町村の数は期間を経るごとに 常に増加している。この人口减少下で都市縮小を呈する市町村は全 期間で最多数であり、直近の 2010 年 2015 年では全体の $72 \%$ 程を 占めている。一方で都市拡大圈域の総数は減少傾向にあり、1995 年 〜2000 年の期間では縮小圏域総数の約 2 分の 1 の程の数であった のに対し、直近の 2010～2015 年の期間では縮小圈域総数の 7 分の 1 程度しか存在していない。

人口規模別のグラフに着目すると、人口減少下で都市縮小を呈す る圏域は 1995 年時点人口が 30 万人以下の圏域群で増加・大多数化 している。特に 30 万 5 万人の圏域では人口減少下で都市縮小の傾 向にある圏域数が 1995 年 2000 年では支配的でなかったものの、 直近の期間で全体の過半数を占める程に増加している。また、30万 人超過圏域についても、支配的であった人口増加下で都市拡大を呈 する圈域の減少と共に、人口減少下で都市縮小の傾向にある圈域の 増加および多数派化が確認できる。 


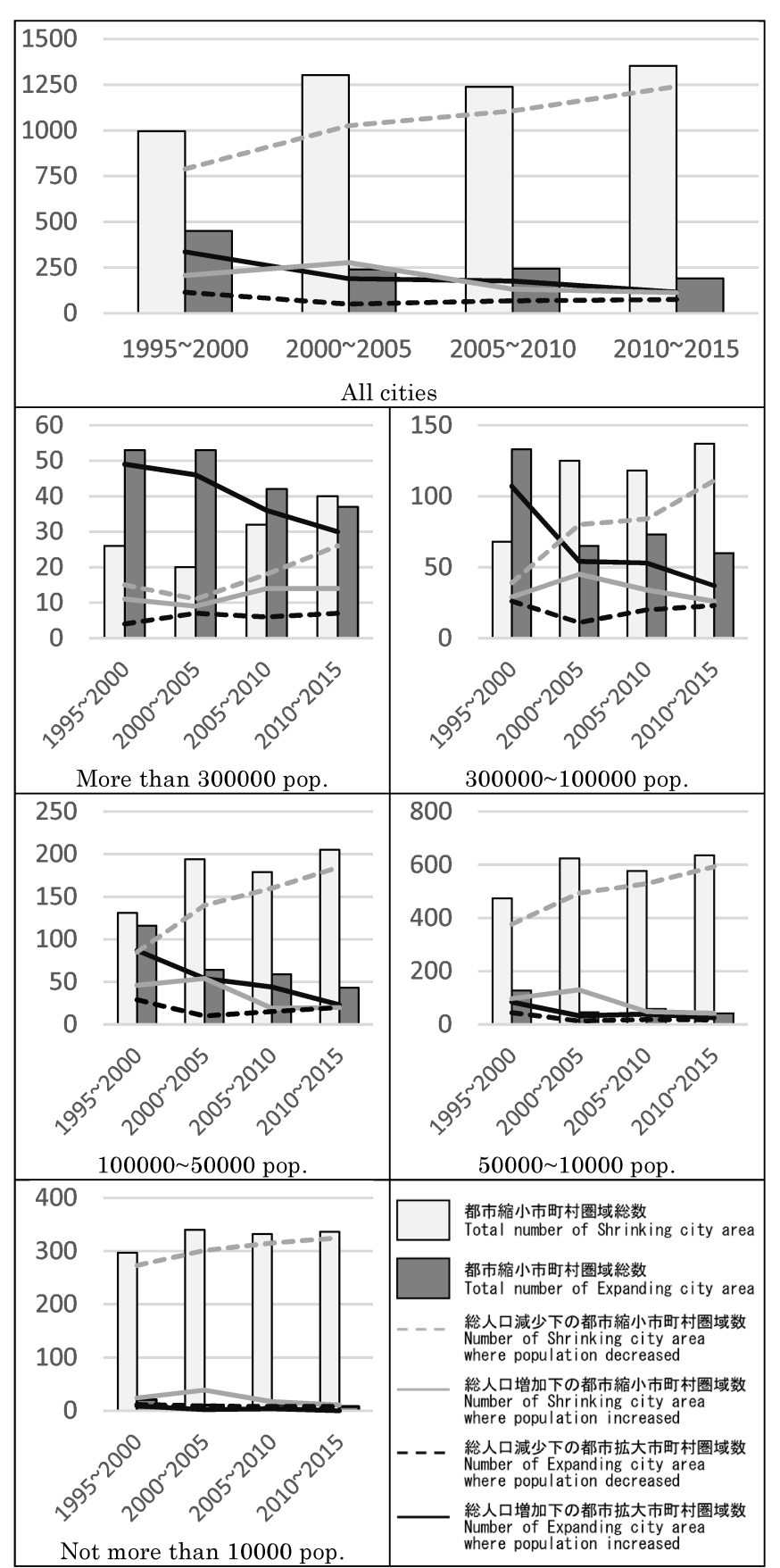

Fig. 4 Changes in the number of cities where urban shrinkage or urban expansion occurred

\subsection{RDID 部分的縮小の発生位置の分析}

続いて各期間における RDID の部分的な縮小地域と RDID 非縮 小地域との空間的接続を圈域ごとに指標化し、市町村の RDID 全体 における縮小の発生位置に関する傾向把握を行う。分析に用いる指 標として、嚴ら（2016）13)の研究を参考に RDID 部分的縮小地域の 非縮小地域に対する隣接性指標 $\left(S \_A d j\right)$ および集積性指標 $\left(S \_I n t\right)$ を Fig. 5 に示すように定義した注 9)。隣接性指標（S_Adj）は RDID の部分的縮小地域の外周が非縮小地域に接している割合を表し、值 が高い圈域ほど対象圈域の部分的縮小が存続する RDIDに隣接して いる傾向が強い。集積性指標 (S_Int) は RDID の部分的縮小地域か ら一定距離範囲内に占める非縮小地域の面積の割合であり、值が高 い圈域ほど RDID が集積している位置で縮小が生じる傾向が強い。
ここで、集積性指標の分析範囲は大きく取りすぎると分析圈域ご との部分的縮小の発生位置の違いによる指標値の差が生じにくくな る。一方で小さく取りすぎると既出の隣接性指標と概ね同様な性質 を持つ指標となり、個別の指標として分析する意味を失う。本研究 では $1500 \mathrm{~m}$ 圈内を分析範囲と設定することで、隣接区域だけでは なく、その一回り外側の区域も参照した部分的縮小地域と RDID 非 縮小地域との近接関係を表す指標として集積性指標を定義した。こ れにより隣接性指標を補完する形でより感度良くにRDID 全体にお ける縮小の発生位置に関する傾向の変化をとらえることが可能だと 考えられる。

$S_{-} A d j=\frac{\sum_{i} S_{-} a d j_{i} \cdot P_{i}}{\sum_{i} P_{i}} \quad\left(\right.$ where $\left.S_{-} a d j_{i}=\frac{l_{i}}{P_{i}}\right)$

$P_{i}$ : Perimeter of a part of shrinking RDID $i(i=1,2, \ldots, n)$

$l_{i}$ : Length of tangential line between $i$ and not shrinking RDID

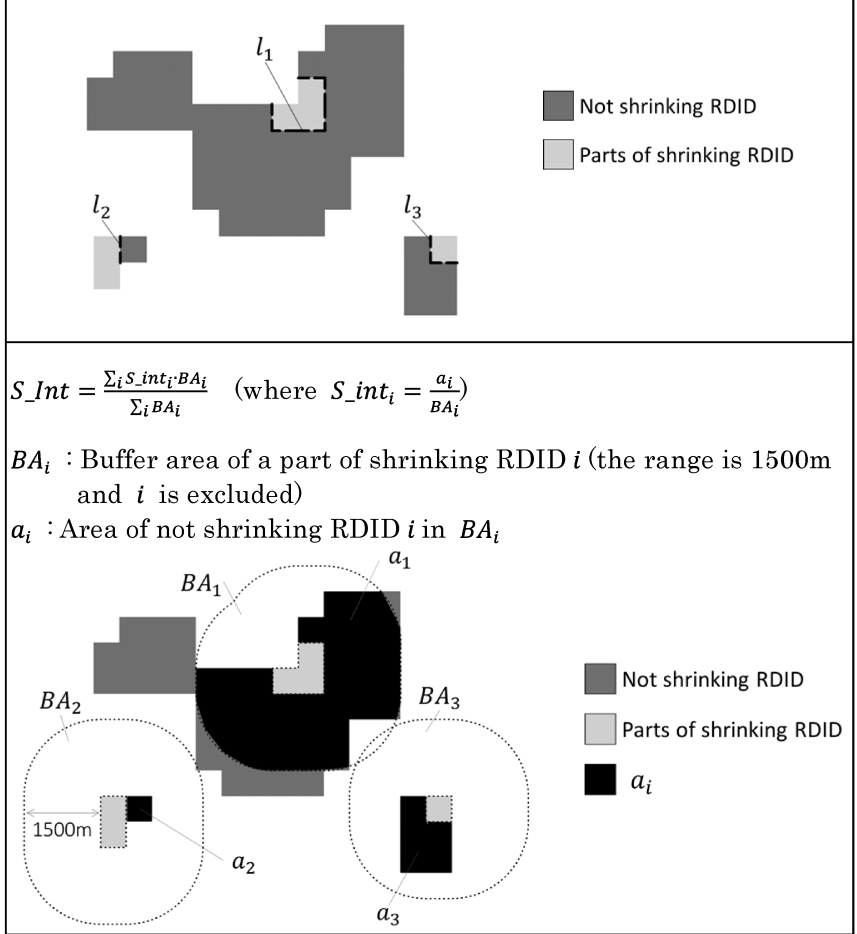

Fig. 5 Definition of adjacency index and integration index

Fig. 6 に市町村全体および 1995 年時点人口規模グループごとの 隣接性指標 $\left(S \_A d j\right)$ および集積性指標 $\left(S_{-}\right.$Int $)$の高低クラス別圈域 数の推移のグラフを示す。これを見ると各人口規模グループに共通 して 2000 年 2005 年の期間で両指標ともに比較的低い值を持つ圈 域数が一時的に増加している。また、2000 年 2005 年より後では期 間を経るごとに比較的高い值の圈域数の増加傾向が認められる。

2000 年 2005 年の期間における各指標值の低い圈域数の増加は、 基本単位区が大きく設定されやすい各市町村圈域の郊外部において 4 章で述べたようなメッシュ人口同定方法の変更による見かけ上の 都市縮小が生じたことが要因として考えられる。一方でその後の 2005 年 2010 年の期間から 2010 年 2015 年の期間にかけての高 い指標值を持つ圈域数の増加は、RDID 同士が隣接あるいは集積し 合う各圈域の中心的位置で縮小が発生する傾向が強まりつつあるこ とを示唆するものと考えられる。 


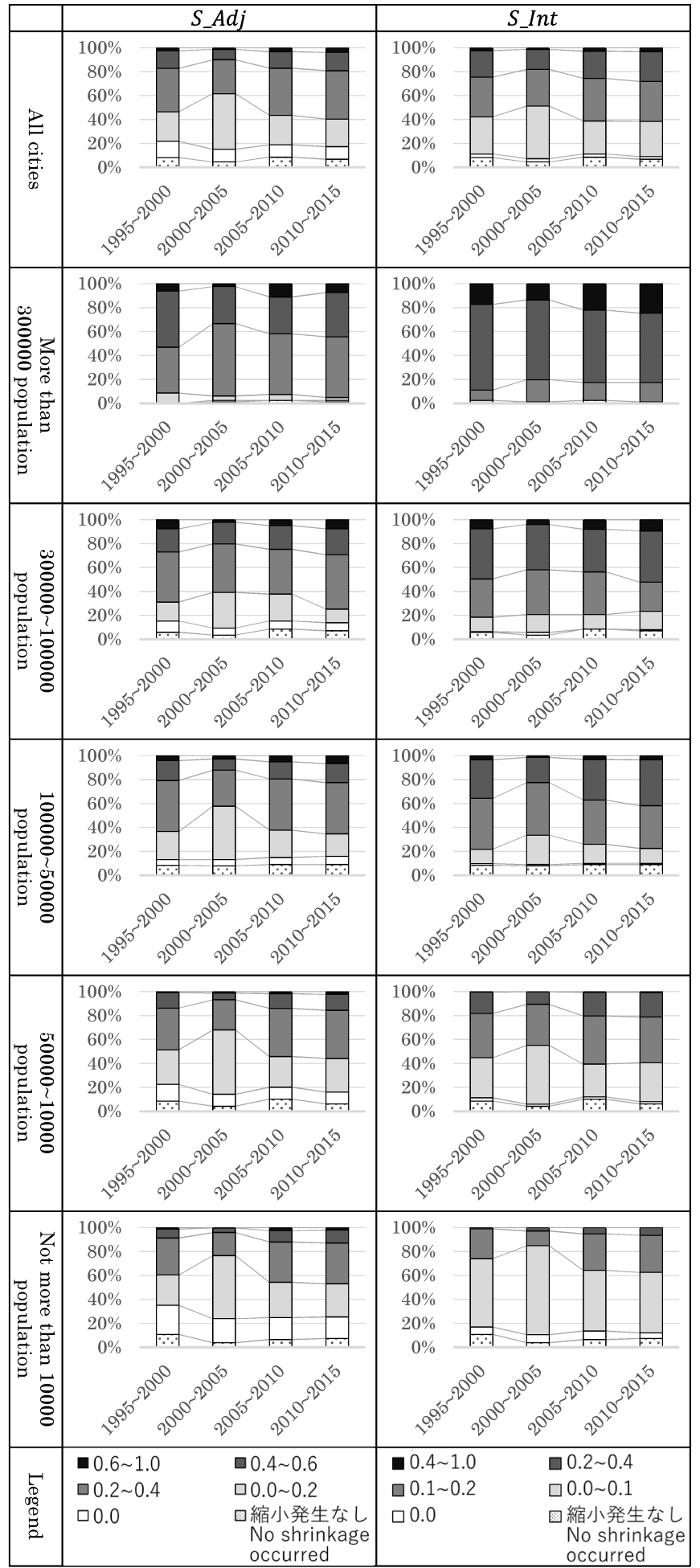

Fig. 6 Percentage changes in the number of cities of each $S_{-}$Adj and S_Int value class

\section{6. 結論}

これまで具体的な分析が行われてこなかった直近の複数期間にお ける全国の全市町村の都市縮小傾向の一端として、本研究から得ら れた代表的知見を以下に示す。

（1）RDID に見る市町村の都市構造変容について、全国的に人口 比としての中心部への集中化傾向が確認できる。また大規模な圏域 では絶対的集中の傾向を示寸圈域の増加も見られる。一方どの人口
規模の市町村についても「7 再都市化 (相対的集中)」の圈域数の増 加が著しく、多くの市町村にて全域的な人口減少の下で中心部の人 口比重が高まる傾向にあることが明らかとなった。

(2) RDID に見る都市縮小発生市町村数に関しては人口減少下で 都市縮小を呈する圈域の数が期間を経るごとに増加しており、直近 では全圈域の約 $72 \%$ を占めるに至る。この傾向はどの人口規模の圈 域群でも確認でき、大規模な圈域でもそれまで支配的であった人口 増加と共に都市拡大が生じるパターンに代わり人口減少下で都市縮 小を呈する圈域が多数派化しつつある。

（3） 2000 年 2005 年より後の期間においては、どの人口規模の 市町村圈域においても RDID 部分的縮小地域の非縮小地域に対する 隣接性指標 $\left(S \_A d j\right)$ および集積性指標 $\left(S_{-}\right.$Int $)$の值が比較的高い圈 域数の増加が確認できる。このことから全国の市町村において RDID が互いに隣接・集積し合う中心的位置で部分的縮小が生じる 傾向が強まりつつあることが示唆された。

（1）および（2）の結果から今後の全国的な人口減少に伴って都 市縮小現象および都市構造の相対的集中化の傾向がさらに広がりを 見せることが予見される。このことから「都市縮小および都市構造 の相対的集中化の潮流をいかにして効率の良い都市構造再構築に結 びつけられるか」が今後の人口減少時代の都市計画制度の重要な観 点となり得る。また（3）の結果は直近の期間における都市縮小が都 市のフリンジだけでなく比較的中心的な位置でも生じていることを 表している。したがって各自治体は縮小後の都市像を想像する際に 単純なフリンジからの縮小ではなく、RDID 等を用いた具体的な縮 小個所の把握に基づいた縮小後の都市像を描く必要があると言える。 以上の知見は人口減少時代の都市計画を考える際の基礎的情報とし て重要なものと考えられる。

本研究における RDID の抽出方法は対象圈域の規模に応じて情報 理論的基準に基づき高密度である区域を抽出できるため、市町村圈 域に限らず定住自立圈や大都市雇用圈などの多様な圈域で「相対的 人口集中地区」を抽出できる。さらに常住人口の代わりに他の観測 対象物の空間分布を利用することで任意の空間データに基づく都市 構造の変容や都市縮小現象を分析することも可能と言える。このこ とから分析者側が適用範囲や利用データを柔軟に設定して多角的に 都市構造変容や都市縮小現象を理解するためのフレームワークの一 例を提示できたことも本研究の一つの寄与と言える。

本研究は過去に発生してきた各現象の発生について市町村単位で 分析し傾向をまとめるに留まっているため、都市構造変容や都市縮 小現象のメカニズムの考察が行われていない。また全国を俯瞰した 分析に注力しており、個々の市町村圏域における縮小発生実態と分 析結果の照合が十分でない。こうした点が研究の課題点と言える。

\section{参考文献}

1) Architectural Institute of Japan: Toshi Syukusyo Jidai no Tochiriyo Keikaku - Tayo na Toshi Kukan Sosyutsu no Tame no Kadai to Taiosaku (Land Use Planning in an era of Urban Shrinking - Issues and Countermeasures for Creating Various Urban Spaces), Gakugei Publishing Company, 2017.8 (in Japanese)

日本建築学会 (編) : 都市縮小時代の土地利用計画 - 多様な都市空間創出 一向けた課題と対応策, 学芸出版社, 2017.8

2) Kawabe, A., Watanabe, S.: CONFIGURATION ANALYSIS OF URBAN CENTERS USING POLYCENTRISM INDICATORS - Urban form 
changes of Japanese cities in an era of shrinking population part 1-, Journal of Architecture and Planning (Transactions of AIJ), Vol.83 No.743, pp.137-144, 2018.1 (in Japanese)

川邊晃大, 渡辺俊：多核性に関する指標を用いた都市圈中心核の形態分析 - 人口減少時代を迎えるわが国の都市圈の形態変化に関する研究 (その 1 ) ，日本建築学会計画系論文集, Vol.83, No.743, pp.137-144, 2018.1

3) Amindarbari, R., Sevtsuk, A.: Measuring Growth and Change in Metropolitan Form, City Form Lab at the Singapore University of Technology and Design UAA2013 in San Francisco, 2013 http://media.voog.com/0000/0036/2451/files/20130320_final.pdf, (accessed 2017-5-2)

4) Osaragi, T.: INFORMATION LOSS MINIMIZATION FOR SPATIAL DATA REPRESENTATION, Journal of Environmental Engineering (Transactions of AIJ), Vol.68 No.574, pp.71-76, 2003.12 (in Japanese) 大佛俊泰: 空間データの視覚化のための情報量損失最小化法, 日本建築学 会環境系論文集, Vol.68 No.574, pp.71-76, 2003.12

5) Kim, C., Onishi, T., Suga, M.: Study on Depopulation and Transformation of Urban Structure - For All Urban Areas in Japan from 1970 to 2000 -, Journal of the City Planning Institute of Japan, Vol.42, No.3, pp.835-840, 2007.10 (in Japanese)

金租基, 大西隆, 菅正史：人口減少と都市構造の変容に関する研究 1970 年〜 2000 年までの日本の全都市圈を対象に - , 公益社団法人日本都 市計画学会 都市計画論文集, Vol.42, No.3, pp.835-840, 2007.10

6) Ariga, T., Matsuhashi, K., Yonezawa, K.: Analysis on Regional Population Distribution Using Estimated Natural Change and Social Change - From Mesh-based National Population Census Data of 19802005 -, Journal of the City Planning Institute of Japan, Vol.46, No.3, pp.847-852, 2011.10 (in Japanese)

有賀俊典, 松橋啓介, 米澤健一：自然増減と社会増減を明示的に考慮した 地域内人口分布の変化 - 1980 年から 2005 年までの全国国勢調査・基準 地域メッシュデータを用いて - , 公益社団法人日本都市計画学会 都市計 画論文集, Vol.46, No.3, pp.847-852, 2011.10

7) Shimizu, H.: Observation and categorization of land use and population / household change in whole Japanese land by using third standard grid cell data - Focusing on urban land use -, Journal of the City Planning Institute of Japan, Vol.50, No.1, pp.107-117, 2015.4 (in Japanese) 清水裕之: 標準地域 3 次メッシュを用いた日本の国土の土地利用の変化と 人口・世帯変化の観察と類型化 - 都市的土地利用に着目して - , 公益社 団法人日本都市計画学会 都市計画論文集, Vol.50, No.1, pp.107-117, 2015.4

8) Kikuchi, R., Muromachi, Y.: Urban and Natural Landuse Changes in the Cities with Population Decrease by National Land Numerical Information, Journal of the City Planning Institute of Japan, Vol.50, No.3, pp.588-593, 2015.10 (in Japanese)

菊池亮太，室町泰徳：国土数值情報を用いた人口減少下の都市における都 市的および自然的土地利用の変化に関する分析, 公益社団法人日本都市 計画学会 都市計画論文集, Vol.50, No.3, pp.588-593, 2015.10

9) Takayanagi, S.: Relationship between poplation change and land use change used by land use subdivision mesh data - Focusing on population density and rate of population change -, Journal of the City Planning Institute of Japan, Vol.52, No.3, pp.459-466, 2017.10 (in Japanese)

高柳誠也：国土数值情報土地利用細分メッシュデータを用いた人口動態 と土地利用変化の関係性 -メッシュ人口密度・メッシュ人口変化率に着 目して - , 公益社団法人日本都市計画学会 都市計画論文集, Vol.52, No.3, pp.459-466, 2017.10

10) Asano, J., Hara, N.: A Study on Characteristics of Shrinkage of Densely Inhabited Districts in Local Cities, Journal of the City Planning Institute of Japan, Vol.49, No.3, pp.651-656, 2014.10 (in Japanese) 浅野純一郎, 原なつみ: 地方都市における DID 縮小区域の発生状況とそ の特性に関する研究, 公益社団法人日本都市計画学会 都市計画論文集, Vol.49, No.3, pp.651-656, 2014.10

11) Hara, N., Asano, J.: A Study on Occurrence Factors and Residential Environment in Shrinkage of Densely Inhabited Districts in Local Non Area-divided Cities, Journal of the City Planning Institute of Japan, Vol.50, No.3, pp.886-891, 2015.10 (in Japanese)
原なつみ, 浅野純一郎：非線引き地方都市における DID 縮小区域の発生 要因と居住環境に関する研究, 公益社団法人日本都市計画学会 都市計画 論文集, Vol.50, No.3, pp.886-891, 2015.10

12) Statistics Bureau of Japan, "Chiiki Messhu Tokei No Sakusei (Making Method of Regional Mesh Statistics)",

https://www.stat.go.jp/data/mesh/pdf/gaiyo2.pdf, (accessed 2019-5-2) 総務省統計局, “地域メッシュ統計の作成”,

https://www.stat.go.jp/data/mesh/pdf/gaiyo2.pdf, (accessed 2019-5-2)

13) Eom, S., Suzuki, T.: On the Quantification of Mixed Land Use Patterns Forcusing on Adjacency, Intensity and Proximity - Classification Considering Mixed Land Use and the Relationship with Travel Behavior in Tokyo Wards Area -, Journal of the City Planning Institute of Japan, Vol.51, No.3, pp.867-874, 2016.10 (in Japanese)

嚴先鏞，鈴木勉：用途間の隣接性・集積性・近接性の観点から見た混合土 地利用パターンの定量化 - 東京 23 区における地区分類と手段別分担率 との関係の分析 - , 公益社団法人日本都市計画学会 都市計画論文集, Vol.50, No.3, pp.886-891, 2015.10

注

注 1）相対的な人口集中地区の規定に際しては圈域の規模に応じて選択され る複数の基準を作成し、それに従って抽出することも可能といえる。しか し、それぞれの規模の圈域に対してどのような值を基準として設定すると より適切な RDID 抽出につながるかが明確でない以上はそうした複数基準 について感覚的に設定せざるをえない。こうしたことから本研究では上記 のような情報理論的アプローチを利用し、情報量という定量的な指標に基 づいた基準值の設定を試みることとする。

注 2) 本研究で用いられる情報量損失最小化法に関してはデータを 2 分する 1 つの境界值を求めるのみであるため、データのソート後に各順位のデー 夕值を境界値として用いた場合の「情報量損失率:L」を小さい順位から順々 に求めていくことで、L が最小となる境界值が簡単に求まる。

注 3）情報量損失最小化法では、あらかじめデータのクラス分け後のクラスの 個数を定めておく必要がある。また值が等しくデータ順位がタイの地区は 一まとめにして 1 つのレコードとして扱う。

注 4） $I_{0}$ は原データによって一意に定まるので、式（3）中の分子「I-I $\left.I_{0}\right\rfloor$ が 最小であるとき、Lは最小となる。ここで、 $I-I_{0}$ は式変形するとクラス分け 前の地点iにおける分配確率の確率分布 $\left(p_{i}\right)$ とクラス分け後の地点iにおけ る分配確率の確率分布 $\left(q_{k}\right.$ ただし $\left.i \in G_{k}\right)$ の間のカルバック・ライブラー 情報量 $\left(\sum_{i} p_{i} \log _{2}\left(p_{i} / q_{k}\right)\right)$ に等しくなる。したがって情報量損失最小化法 はクラス分け前後における地点 $i$ の分配確率の確率分布間のカルバック・ラ イブラー情報量の最小化を行うことと同義と言える。

注 5）総務省統計局「政府の統計空口（e-Stat）」より 1995 2015 年度の国 勢調査結果に基づく $500 \mathrm{~m} メ ッ シ ュ$ 常住人ロデータを入手し利用した。

注 6）本研究では国土交通省「国土数值情報ダウンロードサービス」より全国 の市町村の行政区域データを入手し、各市町村の行政区域データと交差す るメッシュ領域までを当該市町村の圈域として扱う。すなわち、RDID の 抽出にあたっては対象市町村の行政区域データと交差するメッシュの人口 密度データを用いる。

注 7) 本研究では市町村合併による影響を除くため、市町村圈域として 2015 年 1 月 1 日時点の行政区域データを固定して利用する。なお、政令市およ び東京 23 区については区部を一まとめにして 1 圈域として利用した。

注 8）各期間で圈域総人口、RDID 人口、RDID 外部人口、RDID 人口比のい ずれかの増減量が 0 である場合にはあえてどの変容類型にも分類せず、分 析から除いた。

注 9) RDID の部分的縮小について縮小メッシュが隣接している場合、一塊の RDID 部分的縮小地域として扱う。 


\title{
AN ANALYSIS ON URBAN SHRINKAGE TRENDS OF ALL JAPANESE CITIES VIA DETECTING
} RELATIVE DENSELY INHABITED DISTRICT

- Urban form changes of Japanese cities in an era of shrinking population part 2 -

\author{
Akihiro KAWABE ${ }^{* 1}$ and Shun WATANABE ${ }^{* 2}$ \\ ${ }^{* 1}$ Urban Renaissance Agency, Master of Policy and Planning Sciences \\ (Former Grad. Student, Graduate School of Systems and Information Engineering, Univ. of Tsukuba) \\ ${ }^{* 2}$ Prof., Faculty of Engineering, Information and Systems, Univ. of Tsukuba, Ph.D. in Eng.
}

To grasp the actual situations of urban shrinkage dispassionately is considered important for the urban planning in an era of shrinking population in Japan. For analyzing method of the urban shrinkage and urban structure changing in an era of shrinking population, Densely Inhabited District (DID) has been applied in some past studies as an index of urban area. As an issue of this method, shrinkage or urban structure change in the cities where no DID exist or the whole area is DID can't be analyzed.

In the previous paper, we identified Relative Densely Inhabited District (RDID) in whole Japanese cities as the relative population centers which are detected by an urban form analyzing method "Polycentricity" proposed in Amindarbari et al. (2013). the RDID identified in the previous paper is detected by relative density level and population level of each cities, therefore It can be detected in the cities where no DID exist and analyzing the city shrinkage with RDID shrinking as an index. However, the method of setting a density level for RDID in the previous paper tends to overestimate the density level at a large city. Although this setting method can be adjusted by decreasing a parameter to avoid overestimating, the density level with a decreased parameter tends to be underestimated at small cities.

In this paper, we improved the detecting method of RDID applying "Information Loss Minimization" proposed by Osaragi (2003). Applying this method of "Information Loss Minimization" to the setting of density threshold, It is expected that more appropriately RDID criterion can be decided in the sense that the information loss which occurs in classification of density data of the target city becomes the minimum. Furthermore, we identified the urban shrinkage or structure changes in Japanese cities and analyzed the changing those trends from 1995 to 2015 with the RDID applied "Information Loss Minimization" in this paper. The main findings are summarized as follows:

1. With regard to the urban structure, the trends of centralization became stronger. On the other hand, cities where density decreasing in whole area and population weight increasing in center area occurred at the same time tend to have a large proportion in each population size group.

2. The number of cities where the RDID area shrank under population decline is increasing in each population size group in each period from 1995 to 2015 . Those cities accounted for about $72 \%$ of all Japanese cities in the period of 2010 to 2015. This trend can be confirmed in the group of larger cities which the number of cities where the RDID area expanded under population growth was occupied the majority among larger cities in the period of 1995 to 2000 .

3. It was suggested that the number of cities where the RDID shrinkage occur at the central location was increased after the period of 2000 to 2005 . 